\title{
ACCOMMODATIVE AMPLITUDE IN SCHOOL-AGE CHILDREN
}

\author{
Gatis Ikaunieks", Karola Panke, Madara Segliṇa, Aiga Švede, and Gunta Krūmiṇa \\ Department of Optometry and Vision Science, Faculty of Physics and Mathematics, University of Latvia, \\ 1 Jelgavas Str., LV-1004, Rīga, LATVIA \\ \# Corresponding author, gatis.ikaunieks@lu.Iv
}

Communicated by Ivars Lācis

\begin{abstract}
In children, intensive near-work affects the accommodation system of the eye. Younger children, due to anatomical parameters, read at smaller distance than older children and we can expect that the accommodation system of younger can be affected more than that of older children. We wanted to test this hypothesis. Some authors showed that the norms of amplitude of accommodation (AA) developed by Hofstetter (1950) not always could be applied for children. We also wanted to verify these results. A total of 106 (age 7-15) children participated in the study. Distance visual acuity was measured for all children and only data of children with good visual acuity 1.0 or more (dec. units) were analysed (73 children). Accommodative amplitude was measured before and after lessons using subjective push-up technique (with RAF Near Point Ruler). The results showed that the amplitude of accommodation reduced significantly $(\mathrm{p}<0.05)$ during the day and decrease of $A A$ was similar in different age groups (about $\sim 0.70 \mathrm{D}$ ). Additional measurements are needed to verify that the observed changes in $A A$ were associated with fatigue effect. The results showed lower accommodation values compared to average values calculated according to the Hofstetter equation ( $\mathrm{p}<0.05$ ).
\end{abstract}

Key words: accommodative amplitude, visual fatigue, school-age children.

\section{INTRODUCTION}

Good vision at near distances is provided by the accommodative system. Some impairment of this system can lead to asthenopic complaints and reduce visual performance at near distances (Marran et al., 2006). Several studies have evaluated changes in the accommodative system after near tasks. Wolffsohn et al. (2011) showed that the prepresbyopic human accommodative system is robust to fatigue during intense and prolonged (30 min) near-work. Castagno et al. (2016) compared accommodative amplitude values of school-age children measured in the morning and afternoon. He also did not find significant changes of amplitude of accommodation during the day. However, Thiagarajan and Ciuffreda (2013) found that the accommodative system exhibited consistent fatigue effects after near-work in which subjects periodically changed fixation from near to far distances. Iribarren et al. (2001) showed that accommodative facility for office workers decreases during the working day.

Evaluation of the accommodative system during near-tasks for children is also important. Visual screening done by the Department of Optometry and Vision Science, Faculty of Physics and Mathematics, University of Latvia, for 11 000 Latvian school-age children showed that $\sim 21 \%$ of children have problems with the accommodative system (Anonymous, 2014). There is some association between the devel- opment of myopia and higher levels of children's near-work (Mutti et al., 2002; Jones et al., 2007; Ip et al., 2008). The risk of myopia increases if children read at very close distances $(<30 \mathrm{~cm}$ ) (Ip et al., 2008). Younger children prefer to perform near-tasks in closer distances than older children (Wang et al., 2013). Therefore, we could expect that the accommodative system of younger children changes more during the day than that of older children.

One of the parameters of the accommodative system that might change during the day is the amplitude of accommodation (AA). Hasebe et al. (2001) showed that fatigue of the accommodative system reduces tonic accommodation and therefore, also accommodative amplitude might decrease during the day. The aim of this study was to evaluate to what extent the accommodation system in school-age children is subject to fatigue during the day and to determine if these changes are similar for different age groups.

Hofstetter (1950) suggested three equations for computing maximum, minimum, and average norms of accommodative amplitudes for all age groups. Some authors (Sterner et al., 2004; Castagno et al., 2016) showed that measured accommodative amplitude values for children are lower than norms calculated from Hofstetter equations. We also tested if measured values of amplitude of accommodation for children conformed with norms. 


\section{METHODS}

A total of 106 school-age children from grade 2, 7, and 9 participated in the study. For further analysis we used only results of children with habitual visual acuity of 1.0 or more in decimal units and who did not have uncorrected hyperopia. 73 children conformed to these criteria. Participants were divided in three age groups. Average age of groups were $8.4 \pm 0.5$ years (21 subjects), $12.3 \pm 0.4$ years (29 subjects), and $14.8 \pm 0.4$ years (23 subjects). Written consent of children parents was obtained before research. Ethical approval was given by the Ethical Committee of the Institute of Experimental and Clinical Medicine, University of Latvia.

For each subject, distance visual acuity was measured in a morning session. The computer programme Freiburg Visual Acuity and Contrast Test (FrACT) was used to test binocular visual acuity (Bach, 2007). The test stimulus was a Landolt $\mathrm{C}$ optotype oriented at random in one of the four orthogonal directions. Optotypes were presented using an adaptive staircase procedure, in which stimulus size was decreased with log steps, if a child submitted correct answers, and increased, if a child submitted incorrect answers. Test distance was $3 \mathrm{~m}$. Children were asked to indicate the orientation of each stimulus by typing on the computer keyboard. The visual acuity test was performed before lessons and at least three measurements were done in each session. A LCD monitor with background luminance $\sim 90 \mathrm{~cd} / \mathrm{m}^{2}$ (Minolta CS-100 Chroma Meter) was used for the test. Weber contrast of optotypes was 37.7 (Michelson contrast 0.95).

Full optical correction is needed when accommodative amplitude is measured (Burns et al., 2014). We had no time to estimate full refraction for participants. To select only participants with full or close to full optical correction, we used only data from children with habitual binocular visual acuity 1.0 or more (dec. units) and who did not pass the hyperopia test (if it was necessary to perform this test). During the hyperopia test, $+1.50 \mathrm{D}$ glasses were used and a row of 5 Sloan letters corresponding to visual acuity 1.0 was shown on the computer screen. If a child was able to read at least three letters correctly it was assumed that he might have uncorrected hyperopia and their data were not included in result analysis. Test distance was the same as in the visual acuity test -3 metres.

Accommodative amplitude was measured for each child before and after lessons with the push-up method, which is widely used in clinical practice (Atchison et al., 1994). For measurements a R.A.F. rule was used - a rod with a movable target. $1 \mathrm{~mm}$ large letters were used as stimuli. Measurements were done in binocular conditions. During the measurement, one end of the ruler was placed on the child's face. Child was instructed to look at target which was moved closer to his eyes until the child reported the first sustained blur. The distance from this point to the spectacle or cornea plane was recorded. Measurements were done before and after lessons. At least three measurements of accommodative amplitude were done for each child. One source of error in the push-up method is practitioner bias (Burns et al., 2014). To minimise this effect each child was tested by the same person in both sessions.

All measurements were done in schools before and after lessons. Morning session started at $\sim 8: 00$ and afternoon session started at $\sim 13: 30$. All measurements in one session for a child were made within 8 minutes. Illuminance of the test room was kept constant (at least $\sim 250$ lx measured with an illuminance meter T-10, Konica Minolta) in the morning and afternoon sessions.

\section{RESULTS}

Data showed that the amplitude of accommodation decreased ( $p<0.002$, Wilcoxon signed rank test, one-tailed) during the day (Fig. 1) for all children.

Bland Altman analysis was used to determine the average difference between accommodative amplitude measured in both sessions and for calculating repeatability of measurements (Bland and Altman, 1986). Average change in accommodative amplitude was $0.68 \pm 0.18$ D. Repeatability of measurements was 3.12 D (2 SD in Fig. 2).

As expected, separate analysis of accommodative amplitude data for each age group showed that amplitude of accommodation decreased with age (Fig. 3). One-way nonparametric tests did not confirm significance of this relationship ( $p=0.14$, Kruskal-Wallis test), but amplitude of accommodation was significantly lower for the youngest group data, compared with the oldest group ( $p=0.04$, Mann Whitney test, one-tailed).

One of the aims of this study was to determine if accommodative amplitude changes during the day are similar for age groups. The results showed that for each age group accommodative amplitude was lower in the afternoon than in the morning ( $p<0.05$, Wilcoxon signed rank test, one-tailed)

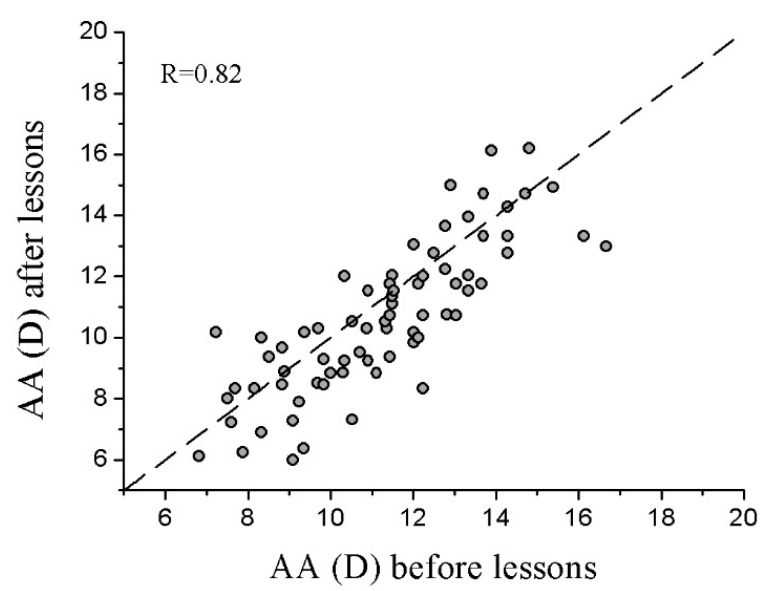

Fig. 1. Amplitude of accommodation (AA) before and after lessons for all participants. Dashed line represents perfect agreement. Data for all subjects showed strong relationship between AA values before and after lessons. R is the Pearson correlation coefficient. AA values after lessons were significantly smaller than in the morning $(p<0.002)$. 


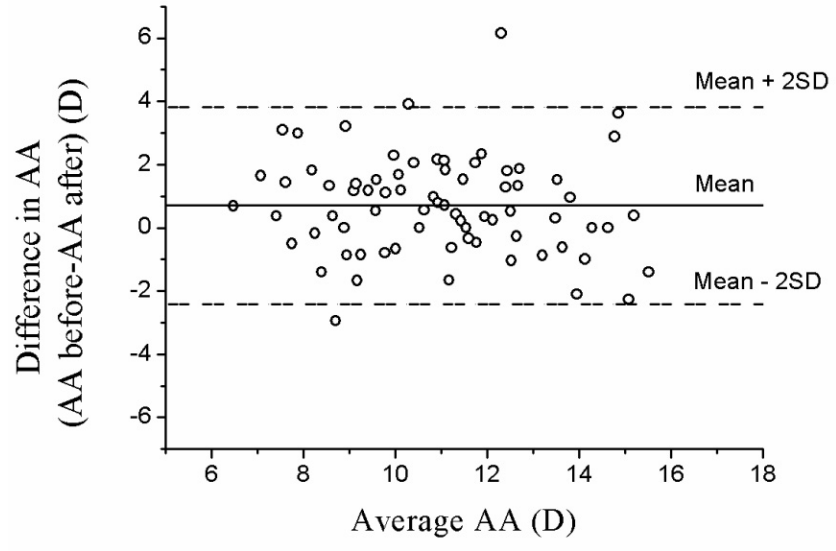

Fig. 2. A Bland-Altman plot showing the difference between accommodative amplitude values before and after lessons.

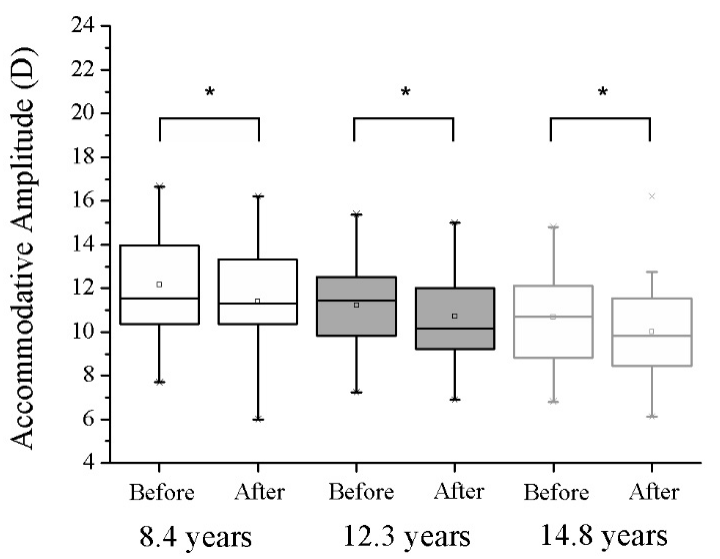

Fig. 3. Amplitude of accommodation (AA) before and after lessons for each age group. The boxes show the median and the first and third quartile. The whiskers represent the range of the data. AA for each age group after lessons was significantly lower than in the morning $(p<0.05)$.

(Fig. 3). The changes in amplitude of accommodation $(\sim 0.70$ D) were similar for the groups ( $p=0.97$, KruskalWallis test).
We compared the measured accommodative amplitude values for each age group with Hofstetter norms. For calculation of minimum and average amplitude by age we used equations (Hofstetter, 1950):

Minimum AA $=15-0.25$ (age (in years))

Average AA $=18.5-0.30$ (age)

Amplitude of accommodation values before and after lessons were lower than average values for all age groups $(p<$ 0.05, Wilcoxon signed rank test) (Fig. 4). Before lessons, amplitude values did not statistically significantly differ from minimum norms $(p<0.05)$. After lessons, accommodative amplitude values were lower than norms $(p<0.05)$. Slopes of regression lines obtained from Hofstetter norms and from measured AA values did not significantly differ $(p=0.38)$.

\section{DISCUSSION}

In this study, the measured accommodative amplitude values were lower than Hofstetter norms (values calculated from Hofstetter equations) (Hofstetter, 1950). Other authors also showed lower accommodative amplitude values than calculated from Hofstetter norms (Sterner et al., 2004; Castagno et al., 2016). We made measurements in binocular conditions. Hofstetter for their equations used accommodative amplitude data measured in monocular conditions (Taub and Shallo-Hoffmann, 2012). Accommodative amplitude measured in binocular conditions is $\sim 2.70 \mathrm{D}$ larger compared with measurements made with a monocular (Sterner et al., 2004). However, our AA data obtained in binocular condition were lower compared with Hofstetter norms. Also other authors have reported this contradiction (Sterner et al., 2004 F). One of reasons why measured values by other authors do not agree with Hofstetter norms could be lack of single standard for amplitude of accommodation measurement, with each author using slightly differ-
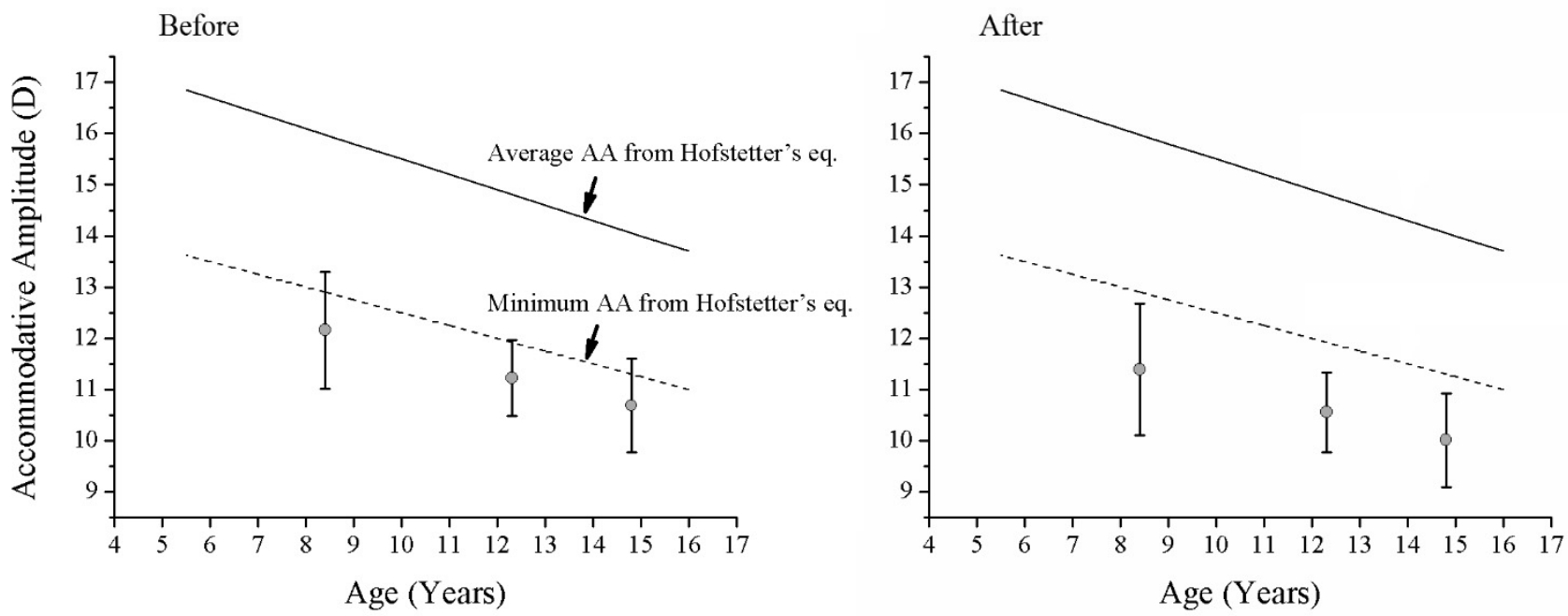

Fig. 4. Amplitude of accommodation (AA) before (left) and after (right) lessons in relation to Hofstetter's equations for minimum (dashed line) and average (solid line) amplitudes. The error bars represent \pm 2 SE. AA after lessons are significantly lower than minimum norms calculated from Hofstetter's equation $(p<0.05)$. 
ent measurements condition (Burns et al., 2014). This might explain why our measured values of accommodative amplitude were not only lower than Hofstetter norms, but also lower than Sterner et al. (2004) measured values. Our estimated accommodative amplitude values were more than 3.00 D smaller than the expected values calculated from the Hofstetter equation. In the study conducted by Sterner $e t$ al. (2004) this difference was 0.80 D. Other reasons of discrepancy between measured and calculated values of accommodative amplitude might be the linear relationship between age and amplitude of accommodation assumed by Hofstetter equations. Real measurements of accommodative amplitude for different age groups show a nonlinear relationship between amplitude and age (Anderson and Stuebing, 2014).

Results showed a decrease of accommodative amplitude during the day. Our results did not agree with those of Castagno et al. (2016), which showed no significant change in amplitude of accommodation during the day. In their study the number of children assessed in the morning and afternoon differed and for statistical analysis they used the Median test to compare groups, not pairs. The authors also mentioned that additional measurements were needed to assess the effect of fatigue on amplitude of accommodation.

There are several factors which could affect our measured values of accommodative amplitude. We did not ask the children what they had been doing before measurements. They could, for example, been using smart phones. Working distance with mobile devices usually is small (Bababekova et al., 2011) and therefore the accommodative system has large stress during this task.

Antona et al. (2009) estimated repeatability of different accommodative amplitude tests and they found out that the push-up method has repeatability $4.76 \mathrm{D}$, which was less suitable than for the push-down and minus lens techniques. In our study the repeatability was $3.12 \mathrm{D}$, which is similar to previous observations (Antona et al., 2009). Decrease in values of accommodative amplitude during the day was $\sim 0.70 \mathrm{D}$, which was quite small compared with repeatability of the test. However, we found changes in accommodative amplitude for all age groups and we can assume that changes in the accommodative system did occur during the day. Hasebe et al. (2001) found out that after some near tasks, which induced fatigue of accommodative system, the reduction of the tonic accommodation was $0.51 \pm 0.09 \mathrm{D}$. This reduction is close to what we found for accommodative amplitude during the day $(0.68 \pm 0.18 \mathrm{D})$. Our data do not indicate if these changes are related with fatigue of the accommodative system or this decrease of accommodative amplitude is a normal physiological change that is not related with fatigue of the visual system. To answer this question control groups with only outdoor activities during the day is needed.

One of the aims of our study was to assess if there are changes in accommodative amplitude during the day in relation to age group. The results showed the same level of decrease of accommodative amplitude in all three groups. We can conclude that, if there is fatigue effect on accommodative system, than this effect is similar between age groups.

\section{REFERENCES}

Anderson, H., Stuebing, K. (2014). Subjective versus objective accommodative Amplitude: Preschool to Presbyopia. Optometry Vis. Sci., 91 (11), 1290-1301

Anonymous (2014). Children in Latvia, 2014. Central Statistical Bureau of Latvia, p. 41. Available at: http://www.csb.gov.lv/sites/default/files/ nr_12_berni_latvija_2014_14_00_lv_en.pdf (last accessed 12.11.2016).

Antona, B., Barra, F., Barrio, A., Gonzalez, E., Sanchez, I. (2009). Repeatability intraexaminer and agreement in amplitude of accommodation measurements. Graefes Arch. Clin. Exper. Ophthalm., 247 (1), 121-127.

Atchison, D., Capper, E., McCabe, K. (1994). Critical subjective measurement of amplitude of accommodation. Optom. Vis. Sci., 71 (11), 699-706.

Bababekova, Y., Rosenfield, M., Hue, J. Huang, R. (2011). Font size and viewing distance of handheld smart phones. Optom. Vis. Sci., 88 (7), 795-797.

Bach, M. (2007). The Freiburg Visual Acuity Test-Variability unchanged by post-hoc re-analysis. Graefe's Arch. Clin. Exper. Ophthalmol., 245 (7), 965-971.

Bland, J. M., Altman, D. G. (1986). Statistical methods for assessing agreement between two methods of clinical measurement. Lancet, 1 (8476), 307-310.

Burns, D. H., Evans, B. W., Allen, P. M. (2014). Clinical measurement of amplitude of accommodation: A review. Optometry in Practice, 15 (3), 75-85.

Castagno, V. D., Vilela, M. A., Meucci, R. D., Resende, D. P., Schneid, F. H., Getelina, R., Nasiloski, M. R., Fassa, A. G. (2016). Amplitude of accommodation in schoolchildren. Current Eye Res., 18, 1-7.

Hasebe, S., Graf, E. W., Schor, C. M. (2001). Fatigue reduces tonic accommodation. Ophthalmic Physiol. Optics, 21 (2), 151-160.

Hofstetter, H.W. (1950). Useful age-amplitude formula. World Optom., 38, $42-45$.

Ip, J. M., Saw, S. M., Rose, K. A., Morgan, I. G., Kifley, A., Wang, J. J., Mitchell, P. (2008). Role of Near Work in myopia: Findings in a sample of Australian school children. Invest. Ophthalmol. Vis. Sci., 49 (7), 2903-2910.

Iribarren, R., Fornaciari, A., Hung, G. K. (2001). Effect of cumulative nearwork on accommodative facility and asthenopia. Int. Ophthalmol., 24 (4), 205-212.

Jones, L., Sinnott, L., Mutti, D., Mitchell, G., Moeschberger, M., Zadnik, K. (2007). Parental history of myopia, sports and outdoor activities, and future myopia. Investig. Ophthalmol. Visual Sci., 48 (8), 3524-3532.

Marran, L., De Land, P., Nguyen, A. (2006). Accommodative insufficiency is the primary source of symptoms in children diagnosed with convergence insufficiency. Optom. Vis. Sci., 83 (5), 281-289.

Mutti, D., Mitchell, G., Moeschberger, M., Jones, L., Zadnik, K. (2002). Parental myopia, near work, school achievement, and children's refractive error. Investig. Ophthalmol. Vis. Sci., 43 (12), 3633-3640.

Sterner, B., Gellerstedt, M., Sjöström, A. (2004). The amplitude of accommodation in 6-10-year-old children - not as good as expected! Ophthalmic Physiol. Optics, 24 (3), 246-251.

Taub, M. P., Shallo-Hoffmann, J. (2012). A comparison of three clinical tests of accommodation amplitude to Hofstetter's norms to guide diagnosis and treatment. Optom. Vis. Devel., 43 (4), 180-190.

Thiagarajan, P., Ciuffreda, K. (2013). Visual fatigue and accommodative dynamics in asymptomatic individuals. Optom. Vis. Sci., 90 (1), 57-65. 
Wang, Y., Bao, J., Ou, L., Thorn, F., Lu, F. (2013). Reading behavior of emmetropic schoolchildren in China. Vis. Res., 86, 43-51.
Wolffsohn, J. S., Sheppard, A. L., Vakani, S., Davies, L. N. (2011). Accommodative amplitude required for sustained near work. Ophthalmic Physiol. Optics, 31 (5), 480-486.

Received 12 November 2016

Accepted in the final form 19 July 2017

\section{AKOMODĀCIJAS AMPLITŪDA SKOLAS VECUMA BĒRNIEM}

Intensīvs tuvuma darbs noslogo bērnu akomodācijas sistēmu. Anatomisko parametru dēl jaunāki bērni lasa tuvākā attālumā nekā vecāki bērni, līdz ar to būtu sagaidāms, ka jaunāko bērnu akomodācijas sistēma ir vairāk noslogota nekā vecākiem bērniem. Mēs vēlējāmies pārbaudìt šo hipotēzi. Dažu autoru pētījumi parādīja, ka Hofstetera (Hofstetter, 1950) izstrādātās akomodācijas amplitūdas normas (AA) ne vienmēr var pielietot bērniem. Arī šo faktu mēs vēlējāmies pārbaudīt. Pētījumā piedalījās 106 bērni vecumā no 7 līdz 15 gadiem. Visiem dalībniekiem tika noteikts tāluma redzes asums. Tālākajā analīzē tika iekḷauti tikai tie bērni, kuru redzes asums bija vismaz 1,0 decimālās vienības (73 bērni). Dalībniekiem pirms un pēc mācību stundām tika novērtēta akomodācijas amplitūda, izmantojot subjektīvo push-up tehniku. Mērījumiem tika izmantots RAF tuvuma punkta lineāls. Rezultāti parādīja būtisku AA samazinājumu dienas laikā visām bērnu vecuma grupām $(p<0,05)$. Lai novērtētu to, ka iegūtais AA samazinājums ir noguruma dēl, ir nepieciešams veikt papildus mērījumus. Iegūtie AA rezultāti bija zemāki, salīdzinot ar aprēḳinātajām vērtībām pēc Hofstetera vienādojuma $(p<0,05)$. 